Quim. Nova, Vol. 35, No. 2, 392-397, 2012

\title{
STUDIES ON THE DEVELOPMENT OF SPECTROPHOTOMETRIC METHOD FOR THE DETERMINATION OF HALOPERIDOL IN PHARMACEUTICAL PREPARATIONS
}

\author{
Nafisur Rahman*, Asma Khatoon and Habibur Rahman \\ Analytical Chemistry Division, Department of Chemistry, Aligarh Muslim University, Aligarh-202002, Uttar Pradesh, India
}

Recebido em 26/2/11; aceito em 18/7/11; publicado na web em 19/8/11

\begin{abstract}
A spectrophotometric method based on the formation of ion-pair complex between haloperidol and eriochrome black $\mathrm{T}(\mathrm{EBT})$ at $\mathrm{pH}$ 1.85 has been described. The formed complex was extracted quantitatively into chloroform and measured at $510 \mathrm{~nm}$. Infra red (IR) studies were performed to confirm the formation of ion-pair complex. Beer's law was obeyed in the concentration range of 2.0-9.0 $\mu \mathrm{g} \mathrm{mL} \mathrm{m}^{-1}$ with molar absorptivity of $2.67 \times 10^{4} \mathrm{~L} \mathrm{~mol}^{-1} \mathrm{~cm}^{-1}$. The detection limit was found to be $0.18 \mu \mathrm{g} \mathrm{mL}$. Statistical comparison of the results of the proposed method with those of the reference method shows excellent agreement and indicates no significant difference in accuracy and precision.
\end{abstract}

Keywords: haloperidol; ion-pair complex; spectrophotometry.

\section{INTRODUCTION}

Haloperidol is a typical antipsychotic drug that chemically belongs to butyrophenone group. It is chemically known as 4-[4-(4-chlorophenyl)-4- hydroxyl-1-piperidyl]-1- (4-fluorophenyl) butan-1-one with molecular weight of $375.86 \mathrm{~g} \mathrm{~mol}^{-1}$. It occurs as a white to pale yellow crystals or powder. Haloperidol is commonly used to treat moderate to severe psychiatric conditions including schizophrenia, manic states and medicament-induced psychosis. ${ }^{1,2}$ It is also used to treat extreme behavior problems in children and to ease the symptoms of Tourett's syndrome. For the treatment of schizophrenia, the required dosage of haloperidol was found to be $5-15 \mathrm{mg}$ per day with an average of $10 \mathrm{mg}$ per day. ${ }^{3}$ The dosage forms are typically tablets and injections. However, haloperidol produces extrapyramidal side effects including acute dystonic reactions, acathisia syndrome, drug induced Parkinsonism, bradykinesia and tardive dyskinesia. ${ }^{4}$ In view of therapeutic importance, it has been planned to develop a sensitive analytical method for assay of haloperidol in pharmaceutical preparations.

Haloperidol has been determined in dosage forms using various analytical techniques such as high performance liquid chromatography, ${ }^{5-7}$ high performance thin-layer chromatography, ${ }^{8-10}{ }^{19}$ F NMR spectroscopy, ${ }^{11}$ square-wave adsorptive stripping voltammetry at a mercury electrode, ${ }^{12}$ square-wave and cyclic voltammety at hanging mercury drop electrode,,$^{13}$ cyclic voltammetry at multi-walled carbon nanotubes-modified glassy carbon electrode,${ }^{14}$ conductometry,,${ }^{15}$ and fluorimetry. ${ }^{16}$ Non aqueous titrimetric, ${ }^{17}$ and UV spectrophotometric, ${ }^{18}$ assay procedures have been described in official compendia.

Spectrophotometry is still popular because of the inherent simplicity, low cost, sensitivity, speed and reliability for determination of drugs in pharmaceutical preparations. The analytical procedures based on spectrophotometry ${ }^{19-21}$ are still being frequently published in the literature. Literature survey revealed that few spectrophotometric methods have been used to determine haloperidol in pharmaceutical preparations. These methods were based on the reaction with $\left[\mathrm{Cr}(\mathrm{NCS})_{6}\right]^{3-},\left[\mathrm{BiI}_{6}\right]^{3}$ and picric acid, ${ }^{15}$ chloranilic acid, ${ }^{22}$ and p-chloranil. ${ }^{23}$ Haloperidol showed absorption maximum at $245 \mathrm{~nm}$ in methanol $-0.1 \mathrm{M} \mathrm{HCl}$ mixture $(9: 1)$ and hence it was determined in commercial dosage forms by UV spectrophotometry. ${ }^{24}$ Derivative

*e-mail: cht17nr_amu @yahoo.com spectrophotometric method has also been reported for quantitation of haloperidol in pharmaceutical preparations. ${ }^{25}$

The aim of the present study was to develop a simple and sensitive spectrophotometric method for the determination of haloperidol in pharmaceutical preparations. The proposed method is based on the formation of ion-pair complex between haloperidol and EBT at $\mathrm{pH}$ 1.85. The ion- pair complex was extracted quantitatively with chloroform and measured spectrophotometrically at $510 \mathrm{~nm}$. The reaction conditions were optimized and validated as per International Conference on Harmonization (ICH) guidelines. ${ }^{26}$

\section{EXPERIMENTAL}

\section{Apparatus}

Spectral runs were made on a Shimadzu UV-visible 1240 spectrophotometer (Kyoto, Tokyo, Japan). All other spectrophotometric measurements were made on Spectronic $20 \mathrm{D}^{+}$spectrophotometer (Milton Roy Company, USA) using $1 \mathrm{~cm}$ matched glass cells. Eutech (Cyber scan $\mathrm{pH} 2100$ ) $\mathrm{pH}$ meter was used to measure the $\mathrm{pH}$. All measurements were performed at $25 \pm 1{ }^{\circ} \mathrm{C}$. The IR spectra were recorded on a Perkin- Elmer FTIR 1650 spectrophotometer using $\mathrm{KBr}$ pellet technique.

\section{Chemicals and reagents}

Haloperidol was purchased from Sigma Chemical Company (St. Louis, MO, USA) and used as received. Commercial tablets of haloperidol such as Trancodol tablet equivalent to $10 \mathrm{mg}$ haloperidol (Intas Laboratories Pvt. Ltd., India) and Senorm tablet equivalent to $10 \mathrm{mg}$ haloperidol (Sun Pharmaceuticals Industries Ltd., India) were purchased from local market. $2.167 \times 10^{-3} \mathrm{M}$ EBT (Fluka Chemie AG, Switzerland, and molecular weight 461.38) solution was freshly prepared in distilled water. Buffer solutions ranging from $\mathrm{pH} 0.65$ 5.20 were prepared using appropriate volumes of $1 \mathrm{M}$ sodium acetate and $1 \mathrm{M} \mathrm{HCl}$.

\section{Standard solution}

An accurately weighed amount (20 mg) of pure haloperidol was transferred into a $100 \mathrm{~mL}$ volumetric flask. The drug was dissolved 
in $10 \mathrm{~mL}$ methanol and then diluted to volume with the same solvent to provide a solution of $0.2 \mathrm{mg} \mathrm{mL}^{-1}$.

\section{General procedure}

Aliquots of standard solutions of haloperidol $\left(0.2 \mathrm{mg} \mathrm{mL}^{-1}\right)$ containing 20-90 $\mu \mathrm{g}$ were pipette into a series of $50 \mathrm{~mL}$ separating funnels. To each separating funnel, $0.85 \mathrm{~mL}$ of $2.167 \times 10^{-3} \mathrm{M}$ EBT was added followed by $2 \mathrm{~mL}$ of buffer solution ( $\mathrm{pH} 1.85$ ). The contents of the separating funnel were shaken vigorously with $10 \mathrm{~mL}$ chloroform for $2 \mathrm{~min}$ and then allowed to separate the two layers. The absorbance of the organic layer was measured at $510 \mathrm{~nm}$ against the reagent blank prepared simultaneously and the calibration curve was constructed. The amount of the drug in pure form and in samples (pharmaceutical preparations) was calculated from the calibration curve, or from the corresponding regression equation.

\section{Procedure for pharmaceutical preparations}

Five tablets (claiming for $10 \mathrm{mg}$ of haloperidol per tablet) were finely powdered and transferred into a small conical flask. Haloperidol was extracted with $2 \times 20 \mathrm{~mL}$ of methanol by shaking. It was filtered through Whatmann filter paper No.42 into $50 \mathrm{~mL}$ volumetric flask to remove excipients. The filtrate was diluted to mark with methanol. The stock solution was diluted to provide a theoretical $0.2 \mathrm{mg} \mathrm{mL}^{-1}$ concentration. The content of haloperidol was determined following the proposed procedure.

\section{Determination of stoichiometry}

The molar combining ratio between haloperidol and EBT was evaluated by Job's method of continuous variations. ${ }^{27}$ In this method, solutions of haloperidol and EBT with identical molar concentrations $\left(2.167 \times 10^{-3} \mathrm{M}\right)$ were mixed in varying volume ratios $(0.1+0.9----0.9+0.1 \mathrm{~mL})$ in such a way that the total volume of each mixture was the same. To each mixture $2 \mathrm{~mL}$ of buffer solution ( $\mathrm{pH} 1.85$ ) was added and then extracted with $10 \mathrm{~mL}$ chloroform. The absorbance of the organic layer was measured at $510 \mathrm{~nm}$ and plotted against the mole fraction.

\section{RESULTS AND DISCUSSION}

EBT is a metallochromic indicator widely used in complexometric titrations. Chemically it is sodium 1-(1-hydroxy-2-naphthylazo)6-nitro-2-naphthol-4-sulphonate ( $\left.\mathrm{NaH}_{2} \mathrm{In}\right)$. As pointed by Schwarzenbach and Biedermann, ${ }^{28}$ the sulphonic acid group on EBT is a strong acid and sodium salt of EBT is completely ionized in acid medium (e.g. $\mathrm{pH}$ 1.85). The equilibria involved can be expressed as:

$$
\mathrm{NaH}_{2} \mathrm{In} \longrightarrow \begin{gathered}
\mathrm{Na}^{+}+\mathrm{H}_{2} \mathrm{In}^{-} \stackrel{\mathrm{pK} 6.3}{\text { Wine red }} \\
\mathrm{HIn}^{2-} \stackrel{\mathrm{pK} 11.5}{\rightleftharpoons} \mathrm{In}^{3-} \\
\text { Blue }
\end{gathered}
$$

Below $\mathrm{pH}$ 6, the aqueous solution of EBT exhibited a wine red colour, ${ }^{29}$ which is due to the presence of 1-(1-hydroxy-2-naphthylazo)6-nitro-2-naphthol-4-sulphonate anion $\left(\mathrm{H}_{2} \mathrm{In}^{-}\right)$. In the present study, haloperidol was found to react with $\mathrm{EBT}$ at $\mathrm{pH} 1.85$, producing an ion-pair complex which was extracted into chloroform. The absorption spectra of haloperidol, EBT at $\mathrm{pH} 1.85$, mixture of haloperidol and EBT at $\mathrm{pH} 1.85$, and ion-pair complex extracted in chloloform are shown in Figure 1. The absorption spectrum of ion pair complex (Figure 1d) shows maximum absorbance at $510 \mathrm{~nm}$. EBT at $\mathrm{pH} 1.85$ could not be extracted into chloroform and thus the reagent blank did not show absorption at $510 \mathrm{~nm}$. The absorption spectrum of EBT at pH 1.85 (in aqueous phase) exhibits maximum absorption at $510 \mathrm{~nm}$. The ion pair complex extracted in chloroform shows higher absorbance as compared to the aqueous phase, indicating that there is no steric hindrance.

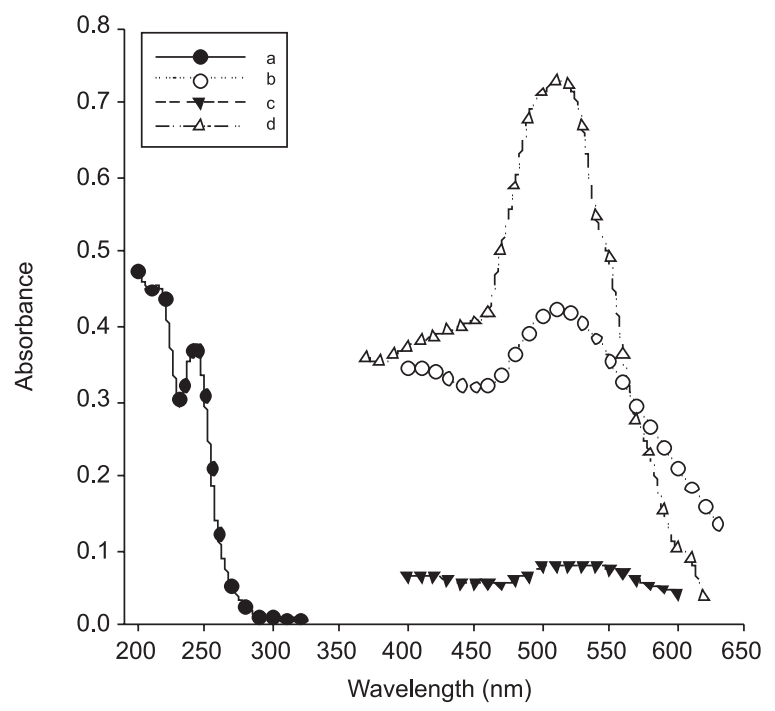

Figure 1. Absorption spectra of (a) $2.66 \times 10^{-5} \mathrm{M}$ haloperidol; (b) $6.50 \times$ $10^{-5} \mathrm{M}$ EBT at $\mathrm{pH} 1.85$ against doubly distilled water; (c) $2.66 \times 10^{-5} \mathrm{M}$ haloperidol $+1.84 \times 10^{-4} \mathrm{M} \mathrm{EBT}$ at $\mathrm{pH} 1.85$ against blank $\left(1.84 \times 10^{-4} \mathrm{M} \mathrm{EBT}\right.$ at $\mathrm{pH} 1.85)$; (d) ion pair complex extracted in $10 \mathrm{~mL}$ chloroform $\left(2.66 \times 10^{-5}\right.$ $M$ of haloperidol and $1.84 \times 10^{-4} \mathrm{M} \mathrm{EBT}$ at $\mathrm{pH} 1.85$ ) against reagent blank (reagent shaken with $10 \mathrm{~mL}$ chloroform)

The stoichiometric ratio of the reactants was evaluated by Job's method of continuous variations. The results (Figure 2) indicated 1:1 ratio for haloperidol with EBT. The formation constant $\left(\mathrm{K}_{\mathrm{f}}\right)$ of the ion-pair complex was calculated using the equation:

$$
K_{f}=\frac{\left(A_{\text {obs }} / A_{\text {extp }}\right) \bar{C}}{\left[C_{D}-\left(A_{\text {obs }} / A_{\text {extp }}\right) \bar{C}\right]\left[C_{R}-\left(A_{\text {obs }} / A_{\text {extp }}\right) \bar{C}\right]}
$$

where $\bar{C}=1.084 \times 10^{-4} \mathrm{M}, C_{D}=1.084 \times 10^{-4} \mathrm{M}$, concentration of haloperidol at the point of maximum complex formation, $C_{R}=1.084 \times$

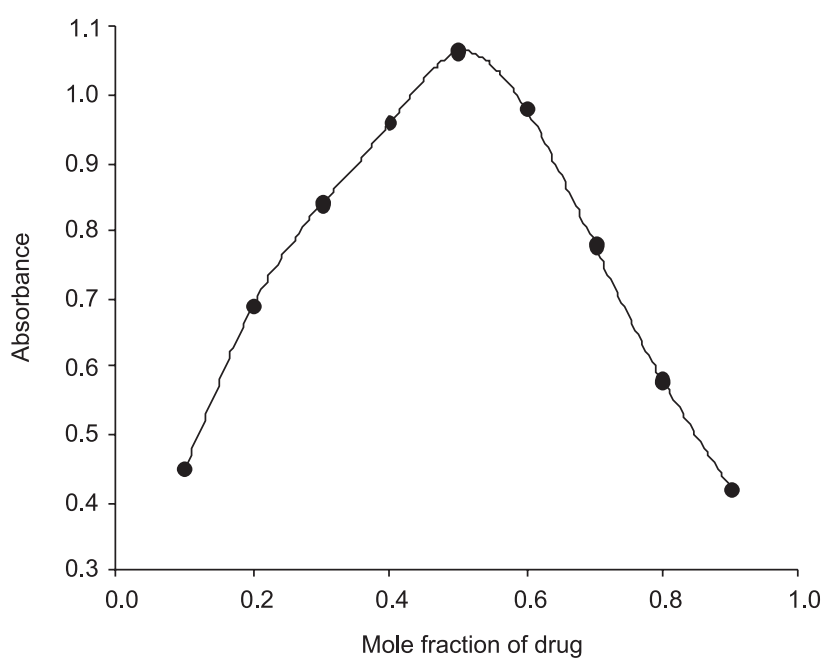

Figure 2. Job's plot to establish the stoichiometry of the reaction using equimolar concentration of haloperidol $\left(2.167 \times 10^{-3} \mathrm{M}\right)$ and $E B T\left(2.167 \times 10^{-3} \mathrm{M}\right)$ 
$10^{-4} \mathrm{M}$; concentration of EBT at the point of maximum complex formation. $\mathrm{A}_{\mathrm{obs}}$ and $\mathrm{A}_{\text {extp }}$ are the measured and extrapolated absorbances at the point of maximum complex formation. $\mathrm{K}_{\mathrm{f}}$ was found to be $5.66 \times 10^{5}$.

The Gibb's free energy, $\Delta \mathrm{G}$, was also calculated using the equation:

$$
\Delta \mathrm{G}=-\mathrm{RT} \ln \mathrm{K}_{\mathrm{f}}
$$

and found to be $-31.79 \mathrm{KJ} \mathrm{mol}^{-1}$.

The $\mathrm{pKa}$ of haloperidol is $8.30^{30}$ which correspond to ionization of piperidine moiety. Hence at $\mathrm{pH} 1.85$, the nitrogen atom of piperidyl group present in its structure is protonated; creating one positive centre. On the other hand, EBT exists as an anion $\left(\mathrm{H}_{2} \mathrm{In}^{-}\right)$at $\mathrm{pH} 1.85$. Thus it can be suggested that one mole of haloperidol associates with one mole of EBT, producing ion-pair complex which was quantitatively extracted into chloroform.

The IR spectra of haloperidol, EBT and haloperidol-EBT ion-pair complex are shown in Figure 3. In the IR spectrum of haloperidol $v(\mathrm{C}=\mathrm{O}), v(\mathrm{C}-\mathrm{F})$ and $v(\mathrm{C}-\mathrm{Cl})$ bands appeared at 1658, 1226 and $740 \mathrm{~cm}^{-1}$, respectively. The IR spectrum of EBT exhibited band at $1507 \mathrm{~cm}^{-1}$ which is assigned to $\mathrm{N}=\mathrm{N}$ stretching vibration. The stretching vibrations due to $-\mathrm{NO}_{2}$ group were observed at 1571 and $1342 \mathrm{~cm}^{-1}$. The $-\mathrm{SO}_{3}$ group showed stretching vibrations at 1218 and $1054 \mathrm{~cm}^{-1}$. The IR spectrum of haloperidol-EBT ion pair complex showed the bands due to stretching vibrations of $\mathrm{C}=\mathrm{O}, \mathrm{C}-\mathrm{F}, \mathrm{C}-\mathrm{Cl}$, $\mathrm{N}=\mathrm{N}, \mathrm{NO}_{2}$ and $\mathrm{SO}_{3}$ groups, thus confirming the formation of ionpair complex extractable into chloroform. The formation of ion-pair complex is shown in Scheme 1.
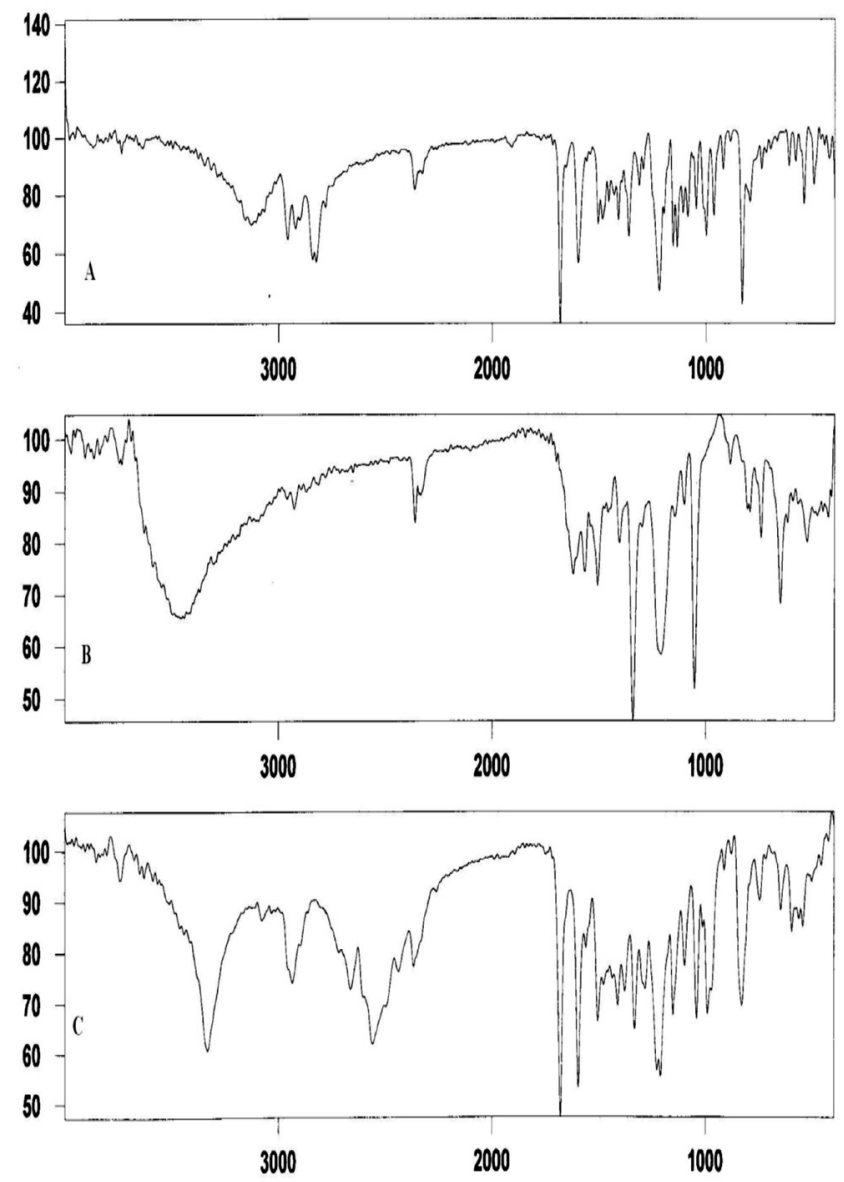

Figure 3. IR Spectra of (A) haloperidol; (B) EBT and (C) ion-pair complex

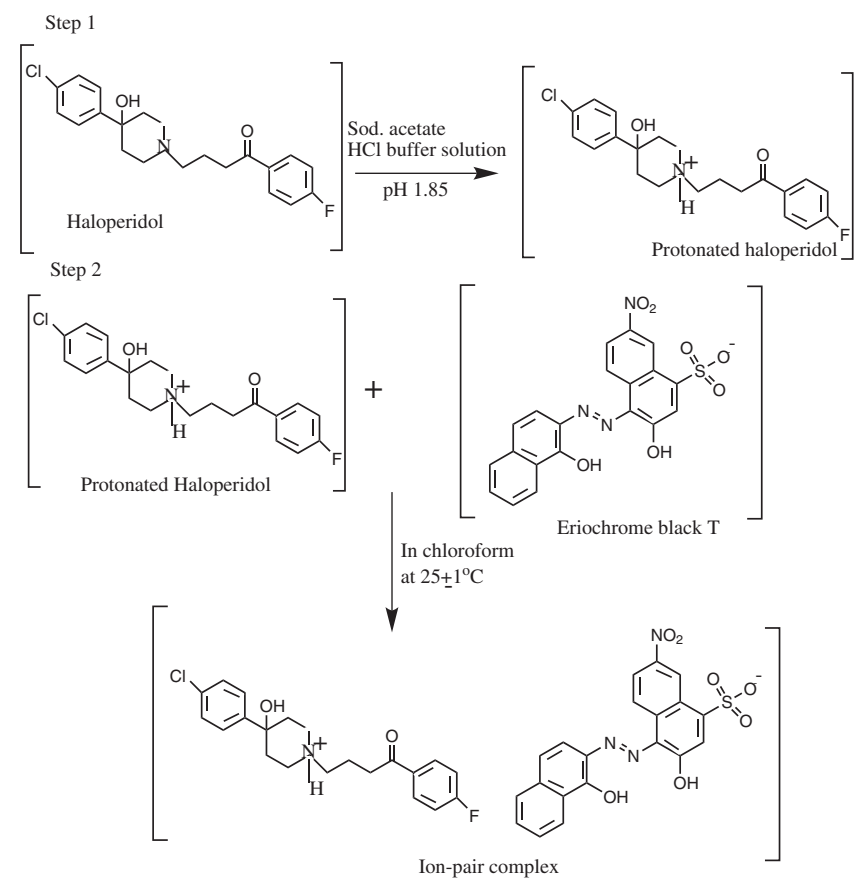

Scheme 1. Reaction mechanism of proposed method

\section{Optimisation of variables}

The different variables that affect the formation of ion-pair complex were critically studied and optimized. The optimum values of the variables were maintained throughout the determination process.

\section{Effect of temperature}

The effect of temperature on the absorbance of the ion pair complex was studied over the range $20-35^{\circ} \mathrm{C}$. It was found that the absorbance of the ion pair complex was constant upto $35^{\circ} \mathrm{C}$. Therefore all measurements were carried out at $25 \pm 1{ }^{\circ} \mathrm{C}$.

\section{Effect of concentration of EBT}

The influence of the concentration of EBT was studied by measuring absorbance of the solutions containing the same concentration of haloperidol $\left(9.0 \mu \mathrm{g} \mathrm{mL}^{-1}\right)$ and varying volumes of $2.167 \times 10^{-3} \mathrm{M}$ EBT. Maximum colour intensity of the complex was obtained with $0.80 \mathrm{~mL}$ of EBT solution (Figure 4). Higher volumes of EBT solution had no pronounced effect on ion-pair complex formation. Therefore $0.85 \mathrm{~mL}$ of $2.167 \times 10^{-3} \mathrm{M}$ EBT solution was chosen as the optimal value for subsequent measurement.

\section{Effect of $p H$}

The influence of the $\mathrm{pH}$ on the formation of the complex was studied by carrying out the reaction in sodium acetate- $\mathrm{HCl}$ buffer solution of $\mathrm{pH}$ range $0.65-5.20$. The results are presented in Figure 5 which indicated that the maximum and constant absorbance was obtained in the $\mathrm{pH}$ range of 1.42 - 4.58. The absorbance of the ion pair complex decreases on increasing the $\mathrm{pH}$ above 4.58. Therefore, buffer solution of $\mathrm{pH} 1.85$ was chosen for the determination process.

\section{Effect of volume of $\mathrm{pH} 1.85$ buffer solution}

The effect of volume of buffer solution ( $\mathrm{pH} 1.85)$ on absorbance was studied in the range of 0.3-3.0 mL. The maximum absorbance was attained with $1.8 \mathrm{~mL}$ and after that the absorbance value remained constant. Therefore $2.0 \mathrm{~mL}$ buffer solution ( $\mathrm{pH} 1.85$ ) was adopted as an optimum volume for all measurements. 


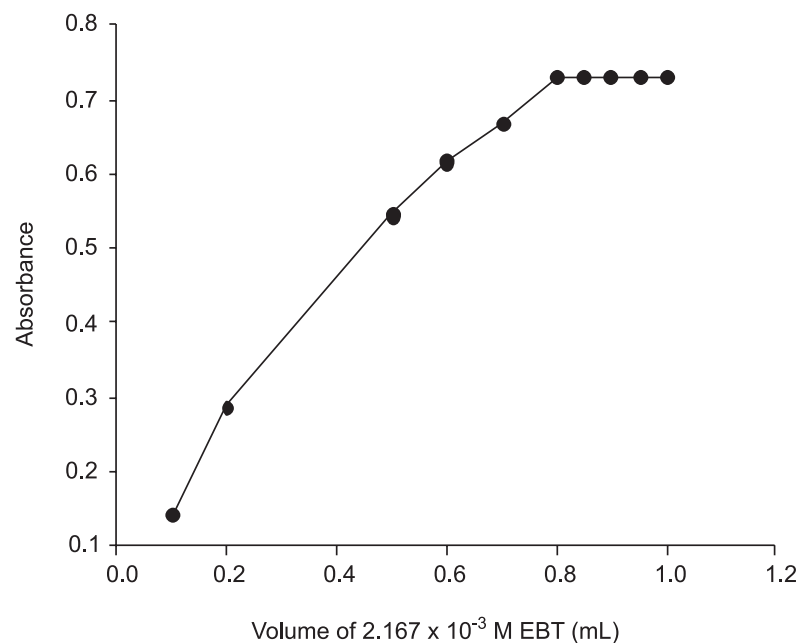

Figure 4. Effect of volume of $2.167 \times 10^{-3} \mathrm{M}$ EBT on the absorbance of ion pair complex

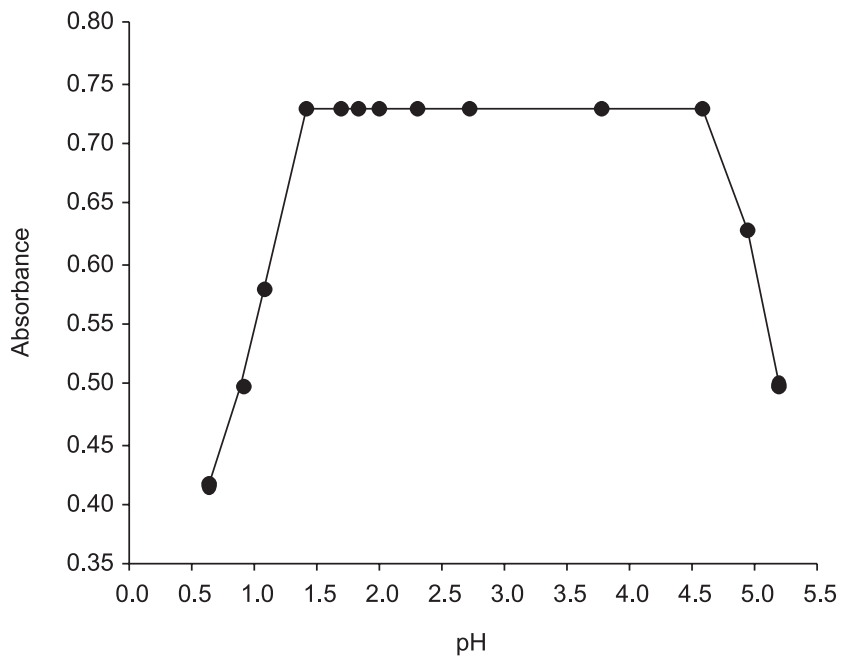

Figure 5. Effect of $p H$ on the absorbance of ion pair complex

\section{Effect of shaking time for extraction}

Shaking time ranging from 0.5-3.0 min were tested to ascertain the extraction of the complex. Maximum and constant absorbance value was obtained when extracted after 1.5 min shaking (Figure $6)$. Therefore, shaking time of 2 min was maintained throughout the experiment.

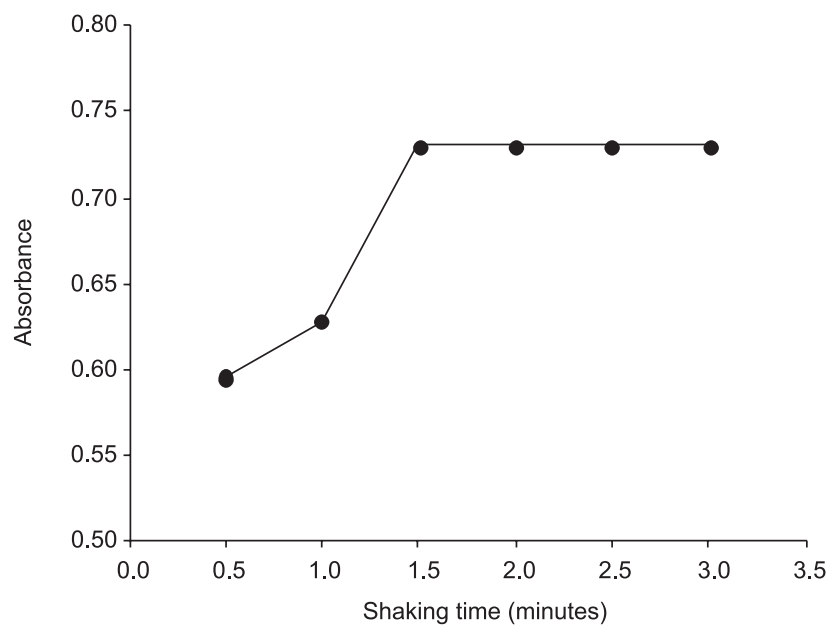

Figure 6. Effect of shaking time for extraction of the ion pair complex
Effect of extracting solvent

The effect of extracting solvent on the ion-pair complex was studied. The organic solvents such as chloroform, carbon tetrachloride, dichloromethane, butanol, isoamyl alcohol and ethyl acetate were examined for extraction of the complex in order to provide efficient extraction procedure. Chloroform was preferred because it provided quantitative extraction of the ion-pair complex from the aqueous solution and gave maximum absorbance of the coloured extract.

\section{Analytical performance}

\section{Linearity and range}

Under the optimum conditions, the standard calibration curve was constructed by plotting the absorbance at $510 \mathrm{~nm}$ as a function of haloperidol concentration. Beer's law range, molar absorptivity, regression equation, correlation coefficient and limits of detection (LOD) and quantitation (LOQ) were calculated and summarized in Table 1. Beer's law was obeyed in the concentration range 2.0-9.0 $\mu \mathrm{g}$ $\mathrm{mL}^{-1}$. The high value of correlation coefficient indicates the good linearity of the calibration curve. The high molar absorptivity of the ion pair complex indicates the high sensitivity of the method. LOD and $\mathrm{LOQ}^{26}$ values were found to be 0.18 and $0.53 \mu \mathrm{g} \mathrm{mL}^{-1}$, respectively.

Table 1. Analytical characteristics of the proposed method

\begin{tabular}{lc}
\hline Parameters & Observed value \\
\hline$\lambda_{\max }(\mathrm{nm})$ & 510 \\
Beer's law limit $\left(\mu \mathrm{g} \mathrm{mL}^{-1}\right)$ & $2.0-9.0$ \\
Molar absorptivity $\left(\mathrm{L} \mathrm{mol}^{-1} \mathrm{~cm}^{-1}\right)$ & $2.67 \times 10^{4}$ \\
Intercept, a & -0.025 \\
Slope, $\mathrm{b}$ & 0.073 \\
Correlation coefficient $(\mathrm{r})$ & 0.9998 \\
LOD $\left(\mu \mathrm{g} \mathrm{mL}{ }^{-1}\right)$ & 0.18 \\
LOQ $\left(\mu \mathrm{g} \mathrm{mL}^{-1}\right)$ & 0.53 \\
\hline
\end{tabular}

\section{Accuracy and precision}

The intra-day precision was evaluated through replicate analysis at 3 concentration levels i.e. $3.0,6.0,8.0 \mu \mathrm{g} \mathrm{mL}^{-1}$ of haloperidol by performing 5 experiments on the same day using the same analyte standard solution. The inter-day precision was assessed using 5 samples of 3 different concentrations on 5 days over a period of a week. The results are summarized in Table 2. It is evident from the table that intra-day and inter-day relative standard deviation (RSD) and error ranged from $0.51-0.64 \%$ and $0.35-0.82 \%$, respectively. It is concluded that the method has good accuracy and precision.

\section{Selectivity}

The selectivity of the proposed method was evaluated with regard to possible interference due to tablet excipients such as lactose, sucrose, magnesium stearate, mannitol and starch. To this end, a mixture of haloperidol with excipients in amounts commonly found in tablets was prepared and analyzed following the proposed procedure. It was observed that the results were not affected by the common excipients.

\section{Robustness}

Robustness was examined by evaluating the influence of small variation in the method variables on its analytical performance. In these experiments, one parameter was changed whereas the others were kept unchanged, and the recovery percentage calculated each time. It was found that variation in the volume of $2.167 \times 10^{-3} \mathrm{M} \mathrm{EBT}$ solution, $0.85 \pm 0.05 \mathrm{~mL}$, and volume of $\mathrm{pH} 1.85$ buffer solution, 
Table 2. The inter- and intra-day precision and accuracy data for determination of haloperidol by proposed method

\begin{tabular}{|c|c|c|c|c|c|c|}
\hline \multirow{2}{*}{ Proposed method } & \multicolumn{2}{|c|}{ Concentration $\left(\mu \mathrm{g} \mathrm{mL}^{-1}\right)$} & \multirow{2}{*}{$\begin{array}{l}\text { Precision } \\
\text { RSD (\%) }\end{array}$} & \multirow{2}{*}{$\begin{array}{l}\text { Accuracy } \\
\text { Error (\%) }\end{array}$} & \multirow{2}{*}{$\mathrm{SAE}^{\mathrm{c}}$} & \multirow{2}{*}{$\mathrm{CL}^{\mathrm{c}}$} \\
\hline & Taken & Found $^{\mathrm{a}} \pm \mathrm{SD}^{\mathrm{b}}$ & & & & \\
\hline \multirow[t]{3}{*}{ Interday } & 3.00 & $2.98 \pm 0.24$ & 0.82 & 0.76 & 0.11 & 0.30 \\
\hline & 6.00 & $6.01 \pm 0.22$ & 0.37 & 0.22 & 0.10 & 0.28 \\
\hline & 8.00 & $7.98 \pm 0.28$ & 0.35 & -0.30 & 0.13 & 0.35 \\
\hline \multirow[t]{3}{*}{ Intraday } & 3.00 & $3.01 \pm 0.16$ & 0.51 & 0.32 & 0.07 & 0.19 \\
\hline & 6.00 & $6.02 \pm 0.39$ & 0.64 & 0.31 & 0.17 & 0.48 \\
\hline & 8.00 & $7.99 \pm 0.46$ & 0.57 & -0.10 & 0.20 & 0.56 \\
\hline
\end{tabular}

${ }^{\mathrm{a}}$ Mean for 5 independent determinations; ${ }^{\mathrm{b}} \mathrm{SD}=$ standard deviation; ${ }^{\mathrm{C}} \mathrm{SAE}=$ standard analytical error ${ }^{\mathrm{d}} \mathrm{CL}=$ confidence limit at $95 \%$ confidence level and 4 degrees of freedom $(t=2.776)$

Table 3. Comparison of the proposed method with existing methods for determination of haloperidol

\begin{tabular}{|c|c|c|c|c|c|c|c|c|}
\hline Techniques/Methods/reagents & $\begin{array}{l}\lambda_{\max } \\
(\mathrm{nm})\end{array}$ & $\begin{array}{l}\text { Linear range } \\
\left(\mu \mathrm{g} \mathrm{m}^{-1}\right)\end{array}$ & $\begin{array}{l}\text { Molar absorptivity } \\
\left(\mathrm{L} \mathrm{mol}^{-1} \mathrm{~cm}^{-1}\right)\end{array}$ & $\begin{array}{c}\text { LOD } \\
\left(\mu \mathrm{g} \mathrm{mL} L^{-1}\right)\end{array}$ & $\begin{array}{l}\text { Recovery } \\
(\%)\end{array}$ & $\begin{array}{l}\mathrm{RSD} \\
(\%)\end{array}$ & Remark & Ref. \\
\hline \multicolumn{9}{|l|}{ Spectrophotomety } \\
\hline$\left[\mathrm{Cr}(\mathrm{CNS})_{6}\right]^{3-}$ & 329 & $0.15-1.14$ & $1.46 \times 10^{4}$ & - & - & - & \multirow{3}{*}{$\begin{array}{l}\text { Precipitate were } \\
\text { formed, then } \\
\text { they were dis- } \\
\text { solved in appro- } \\
\text { priate solvents }\end{array}$} & 15 \\
\hline$\left[\mathrm{BiI}_{6}\right]^{3-}$ & 489 & $0.21-1.57$ & $2.85 \times 10^{4}$ & - & - & - & & 15 \\
\hline Picric acid & 422 & $0.06-0.91$ & $8.57 \times 10^{4}$ & - & - & - & & 15 \\
\hline Chloranilic acid & 576 & $95.60-215.14$ & - & - & 100.41 & 1.17 & $60 \mathrm{~min}$ required & 22 \\
\hline Methanol-HCl (9:1) & 245 & $2.50-12.50$ & - & - & 100.28 & 0.25 & immediate & 24 \\
\hline EBT & 510 & $2.0-9.0$ & $2.67 \times 10^{4}$ & 0.18 & 100.13 & 0.44 & immediate & This work \\
\hline $\begin{array}{l}\text { First derivative Spectrophotometry } \\
\text { with base line to peak technique }\end{array}$ & 253 & $4.56-22.82$ & - & 0.87 & $96.0-106.3$ & 2.20 & - & 25 \\
\hline HPTLC & - & $10-100 \mathrm{ng} \mu \mathrm{L}^{-1}$ & - & $0.89 \mathrm{ng}_{\mu} \mathrm{L}^{-1}$ & $97.76-100.33$ & $<4.5$ & - & 8 \\
\hline${ }^{19} \mathrm{~F}$ NMR & - & $60-600$ & - & 1.40 & $96.0-103.0$ & $<8$ & - & 11 \\
\hline
\end{tabular}

$2.0 \pm 0.2 \mathrm{~mL}$, did not significantly affect the procedure. The proposed method is reliable during normal usage and considered to be robust.

Table 3 shows the comparison of the performance of the proposed method with other existing methods for the determination of haloperidol in pharmaceutical preparations. The existing spectrophotometric methods are tedious ${ }^{15}$ and time consuming. ${ }^{15,22}$ The derivative spectrophotometric method ${ }^{25}$ has acceptable linear range with higher RSD values. The HPLC, HPTLC and ${ }^{19}$ FNMR methods are sensitive with good linear range. The RSD values for these methods are also higher. In addition, all analytical laboratories cannot afford to keep these instrumentations owing to high cost. In comparison, the proposed method is simple and sensitive employing only a cheaper reagent.

\section{Analysis of dosage forms}

Two different brands of tablet samples were analysed by the proposed method and a reference method. ${ }^{23}$ The results were presented in Table 4. The results obtained by the proposed and reference methods were compared statistically. The student's t- and F- tests showed that the calculated $\mathrm{t}$ - and F-values are less than the theoretical values at $95 \%$ confidence level. This indicated good precision and accuracy in the analysis of haloperidol in tablets. Interval hypothesis test ${ }^{31}$ was also performed to calculate lower $\left(\theta_{\mathrm{L}}\right)$ and upper $\left(\theta_{\mathrm{u}}\right)$ confidence limits at $95 \%$ confidence level based on recovery experiments. It was found that in both cases; $\theta_{\mathrm{L}}$ and $\theta_{\mathrm{u}}$ values were within $\pm 2 \%$; confirming the compliance of regulatory authority. ${ }^{32}$

\section{CONCLUSION}

The proposed method is rapid, simple, sensitive and accurate which can be used for determination of haloperidol in pharmaceutical
Table 4. Point and interval hypothesis tests: Applicability of the proposed method in pharmaceutical preparations and its comparison with the reference method at $95 \%$ confidence level

\begin{tabular}{lcc}
\hline $\begin{array}{l}\text { Pharmaceutical formulations } \\
\text { (labelled amount) }\end{array}$ & \multicolumn{2}{c}{ Amount found $\pm \mathrm{SD}(\mathrm{mg})$} \\
\cline { 2 - 3 } & Proposed method $^{\mathrm{a}}$ & Reference method \\
\hline Trancodol-10 & $10.01 \pm 0.04$ & $9.98 \pm 0.18$ \\
$(10 \mathrm{mg})$ & $\mathrm{F}=1.14$ & \\
& $\mathrm{t}=0.02$ & \\
& $\theta_{\mathrm{L}}^{\mathrm{b}}=0.99$ & \\
& $\theta_{\mathrm{U}}^{\mathrm{b}}=1.01$ & \\
Senorm-10 & $10.01 \pm 0.02$ & $9.99 \pm 0.31$ \\
$(10 \mathrm{mg})$ & $\mathrm{F}=1.69$ & \\
& $\mathrm{t}=0.74$ & \\
& $\theta_{\mathrm{L}}^{\mathrm{b}}=0.99$ & \\
& $\theta_{\mathrm{U}}^{\mathrm{b}}=1.00$ & \\
\hline
\end{tabular}

${ }^{\text {a Average of } 5 \text { determinations; }{ }^{\mathrm{b}} \mathrm{A} \text { bias, based on recovery experiments, of } \pm 2 \%}$ is acceptable. Theoretical $\mathrm{t}(\mathrm{v}=8)$ and $\mathrm{F}$ values at $95 \%$ confidence level are 2.306 and 6.39 , respectively.

preparations. The method presented is based on the formation of chloroform extractable ion-pair complex with EBT. The method makes use of a common and simple reagent which an ordinary analytical laboratory can afford. The extractive spectrophotometric method has the advantage that it allows the separation of haloperidol from other auxiliary substances. In addition, Beer's law is obeyed in the concentration range $2.0-9.0 \mu \mathrm{g} \mathrm{mL} \mathrm{m}^{-1}$. The main advantage of this method is low cost of reagent and apparatus used and short analysis time.

\section{ACKNOWLEDGMENTS}

The authors are grateful to chairman Department of Chemistry, 
Aligarh Muslim University for providing research facilities. One of the authors (A. Khatoon) is grateful to Aligarh Muslim University for providing Non Net UGC fellowship to carry out this work.

\section{REFERENCES}

1. Gilbert, M. M.; Curr. Ther. Res. 1969, 11, 520.

2. Hollister, L. E.; Basic and Clinical Pharmacology, $6^{\text {th }}$ ed., Prentice-Hall: London, 1995, p. 432.

3. Singh, O. P.; Chakraborty, I.; Dasgupta, A.; Datta, S. A.; Indian J. Psychiatry 2008, 50, 171.

4. Cesario, V.; Recent Prog. Med. 2008, 99, 146.

5. Wate, S. P.; Bosker, A. A.; Int. J. ChemTech. Res. 2009, 1, 675.

6. Ali, I.; Aboul-Enien, H. Y.; J. Liq. Chromatogr. Relat. Technol. 2005, 28, 3169.

7. Petkovska, R.; Dimitrovska, A.; Acta Pharm. 2008, 58, 243.

8. Mennickent, S.; Pino, L.; Vega, M.; Godoy, C. G.; De-Diego, M.; J. Sep. Sci. 2007, 30, 772 .

9. Mennickent, S.; Pino, L.; Vega, M.;Diego, M.; J. Sep. Sci. 2008, 31, 201.

10. Maslanka, A.; Krzek, J.; J. AOAC Int. 2005, 88, 70.

11. Shamsipur, M.; Shafiee-Dastgerdi, L.; Telebpour, Z.; Haghgoo, S.; J. Pharm. Biomed. Anal. 2007, 43, 1116.

12. El- Desoky, H. S.; Ghoneim, M. M.; J. Pharm. Biomed. Anal. 2005, 38 , 543.

13. Ribeiro, F. W. P.; Soares, J. E. S.; Becker, H.; De-Souza, D.; de LimaNeto, P.; Correia, A. N.; Electrochim. Acta 2011, 56, 2036.

14. Huang, F.; Peng, Y.; Jin, G.; Zhang, S.; Kong, J.; Sensors 2008, 8, 1879

15. Kurzawa, M.; Kowalezyk-Marzec, A.; Szlyk, E.; Chem. Anal. 2004, 49, 91.

16. Rahman, N.; Siddiqui, S.; Drug Test. Anal. 2010, 2, 252.

17. European Pharmacopoeia; Council of Europe: Strasbourg, 2002, p. 1288.
18. Chinese Pharmacopoeia; Chinese Pharmacopoeia Commission, Chemical Industry Press: Beijing, 2005, p. 469.

19. Nagaraja, P.; Shrestha, A. K.; Shivakumar, A.; Al-Tayar, N. G. S.; Gowda, A. K.; Quim. Nova 2011, 34, 373.

20. Rufino, J. L.; Weinert, P. L.; Pezza, H. R.; Pezza, L.; Quim. Nova 2009, 32, 1764.

21. Önal, A.; Quim. Nova 2011, 34, 677.

22. Attama, A. A.; Nnamani, P. O.; Adikwu, M. U.; Akidi, F. O.; Chem. Pharm. Bull. 2004, 52, 303.

23. Shingbal, D. M.; Joshi, S. V.; Indian Drugs 1985, 22, 326.

24. Wate, S. P.; Borkar, A. A.; Indian J. Pharm. Sci. 2010, 72, 265.

25. Stolarczyk, M.; Apola, A.; Krzek, J.; Sajdak, A.; Acta Pol. Pharm. 2009, 66,351

26. International Conference on Harmonisation of Technical Requirements for Registration of Pharmaceuticals for Human Use; ICH Harmonized Tripartite Guideline, Validation of Analytical Procedures: Text and Methodology, Q2(R 1), Complementary Guideline on Methodology dated 06 November 1996, incorporated in November 2005, London.

27. Skoog, D. A.; West, D. M.; Holler, F. J.; Crouch, S. R.; Fundamentals of Analytical Chemistry, $8^{\text {th }}$ ed., Thomson and Brooks: California, 2004.

28. Schwarzenbach, G.; Biedermann, W.; Helv. Chim. Acta 1948, 31, 678.

29. Welcher, W. J.; The Analytical use of Ethylenediamine Tetraacetic Acid, $1^{\text {st }}$ ed., D. van Nostrand Company, Inc.: New York, 1958.

30. Al Omari, M. M.; Zughul, M. B.; Devies, J. E. D.; Badwan, A. A.; J. Solution Chem. 2009, 38, 669.

31. Hartman, C.; Smeyers-Verbeke, J.; Pinninckx, W.; Heyden, Y. V.; Vankeerberghen, P.; Massart, D. L.; Anal. Chem. 1995, 67, 4491.

32. Canada Health Protection Branch, Ministry of National Health and Welfare; Acceptable Methods in Drugs Directorate Guidelines, Draft: Ottawa, 1992 